\title{
Predation of epipelic diatoms by the amphipod Corophium volutator and the polychaete Nereis diversicolor
}

\author{
David Smith ${ }^{1, *}$, R. G. Hughes ${ }^{1, * *}$, Eileen J. Cox ${ }^{2}$ \\ ${ }^{1}$ School of Biological Sciences, Queen Mary and Westfield College, University of London, London E1 4NS, United Kingdom \\ ${ }^{2}$ Department of Botany, The Natural History Museum, Cromwell Road, London SW7 5BD, United Kingdom
}

\begin{abstract}
The effects of Corophium volutator (Pallas) and Nereis diversicolor (O. F. Muller) on the densities and specific compositions of epipelıc diatom assemblages were investigated experimentally, in the laboratory and in an estuary. In laboratory experiments cores containing no macrofauna had significantly higher densities of dictoms than cores with $C$. volutator and cores with $N$. diversicolor after $8 \mathrm{~d}$. In field experiments the densities of diatoms increased where $C$. volutator were removed, by spraylng with insecticlde, and where $V$. diversicolor were prevented from surface deposit feeding, by the insertion of porous mats under the surface. The mean dally rates of consumption of diatons by individual $C$. volutator and $N$. diversicolor in the field were estimated to be 2150 to 3767 and 5476 to 12184 cells respectively. In the laboratory the effects of $C$. volutator and $N$ diversicolor on the species composition of the diatom assemblage were similar. In the field the assemblages that developed where predation was reduced were different because of intial differences in diatom assemblage structure in the 2 experimental areas. The laboratory results showed that $C$. volutator and $N$. diversicolor may feed on the same species of diatoms when presented with the same diatom assemblage, indicating that interspecific competition for food may be important under some natural conditions.
\end{abstract}

KEY WORDS: Corophium volutator Nerels diversicolor Epıpelic diatoms Predation

\section{INTRODUCTION}

Corophium volutator and Nereis diversicolor are often very abundant in estuarine and coastal mudflats of northwestern Europe where densities greater than $100000 \mathrm{~m}^{-2}$ (Gerdol \& Hughes 1993) and $50000 \mathrm{~m}^{-2}$ (Möller 1985) respectively have been reported. C. volutator live in U-shaped burrows up to $5 \mathrm{~cm}$ deep and are predominantly unselective deposit feeders (Gerdol \& Hughes 1994a, b), although suspension feeding and epipsammic browsing may also occur. The amphipods scrape surface sediment into their burrow with their antennae (Meadows \& Reid 1966). The sediment is drawn into the setal basket formed by the second

\footnotetext{
- Present address: Department of Biology, University of Essex, Colchester CO4 3SQ, UK

-Addressee for correspondence.

E-mail: r.hughes@qmw.ac.uk
}

gnathopods, by the respiratory current produced by the beating pleopods, and sorted before food particles are passed to the mouth

Nereis diversicolor also has 3 feeding methods: the worms may be scavengers/predators, suspension feeders or surface deposit feeders (Fauchald \& Jumars 1979, Reise 1979, Riisgård 1991, Jensen \& Andre 1993), of which the last 2 are the main methods (Pashley 1986, Esselink \& Zwarts 1989). In suspension feeding a mucous funnel extends from the entrance of the burrow, which may be about $15 \mathrm{~cm}$ deep (Davey 1994), down to the worm which produces a current of water by undulating its body. Suspended food particles are trapped on the funnel which is then ingested (Harley 1950). In surface deposit feeding the worms partially emerge from their burrows, swallow some surface sediment by everting their proboscis, and retreat back into their burrows leaving furrows which radiate from the burrow opening. Suspension feeding cannot occur 
when no surface water remains during periods of low tide, and may be unprofitable in muddy estuaries (as in this study) because of the relatively low concentration of food particles among the high load of suspended inorganic material (Esselink \& Zwarts 1989). Deposit feeding may be more profitable, but it increases the risk of predation by fish and birds. Esselink \& Zwarts (1989) and Riisgắrd (1991) concluded that suspension feeding was the predominant feeding method. In contrast, Pashley (1986) considered that $N$. diversicolor was an opportunist that relied mainly on deposit feeding but changed to other, more energy-rich, food sources when they became available. In the estuaries of Essex (SE England) when the sediment is exposed by the tide there is often no overlying water, possibly because the burrows of $N$. diversicolor drain the surface sediment (Meadows \& Tait 1989), and suspension feeding is not possible. The presence of radiating furrows indicates that deposit feeding occurs regularly, as has been observed often (Fig. 1).

The relationships between Corophium volutator and Nereis diversicolor have been studied extensively. Some authors have found that the 2 species coexist (Möller 1986, Flach 1992, Jensen \& Andre 1993), while others, including Hughes \& Gerdol (in press), who examined their distributions in 2 Essex estuaries, have recorded negative correlations between their densities. $N$. diversicolor may eat $C$. volutator (Rönn et al. 1988), deter recruitment of the amphipods, or cause their migration (Bornsdorff et al. 1986, Ólafsson \& Persson 1986, Jensen 1988, Jensen \& Andre 1993). Disturbance by the amphipods may prevent colonisation by small $N$. diversicolor but there is little evidence of this (see Hughes \& Gerdol in press).
The role of interspecific competition for food in determining the distribution and abundance of the 2 species has not been examined previously. Interspecific competition for food is possible since both species may feed on surface deposits and consume epipelic diatoms and detritus. Epipelic diatoms are often very abundant in the top few millimetres of intertidal mudflats (Underwood \& Paterson 1993a). Gerdol \& Hughes (1994b) have shown that predation by Corophium volutator reduces the abundance of epipelic diatoms, but there is no similar quantitative study on the effects of Nereis diversicolor.

This study examined the comparative effects of Corophium volutator and Nereis diversicolor on the abundance of epipelic diatoms, and on the specific composition of the diatom assemblage, in order to identify any differential resource utilisation. The approach was to use laboratory experiments, where both species were offered the same food under controlled conditions, and field exclusion experiments, which made use of natural areas where only one or the other species occurs

\section{METHODS}

Laboratory experiments. Fifteen corers, $14 \mathrm{~cm}$ diameter and $15 \mathrm{~cm}$ long, were used to collect cores of sediment $10 \mathrm{~cm}$ deep from a site at Battlesbridge (River Crouch, Essex, UK) where no macrofauna occur in the sediment (for unknown reasons). The cores of sediment were taken to the laboratory and placed in an artificial tidal. regime of $3 \mathrm{~h}$ submergence every $12 \mathrm{~h}$, using water of 30 salinity at $12^{\circ} \mathrm{C}$ and in $12 \mathrm{~h}$ light $/ 12 \mathrm{~h}$ dark.

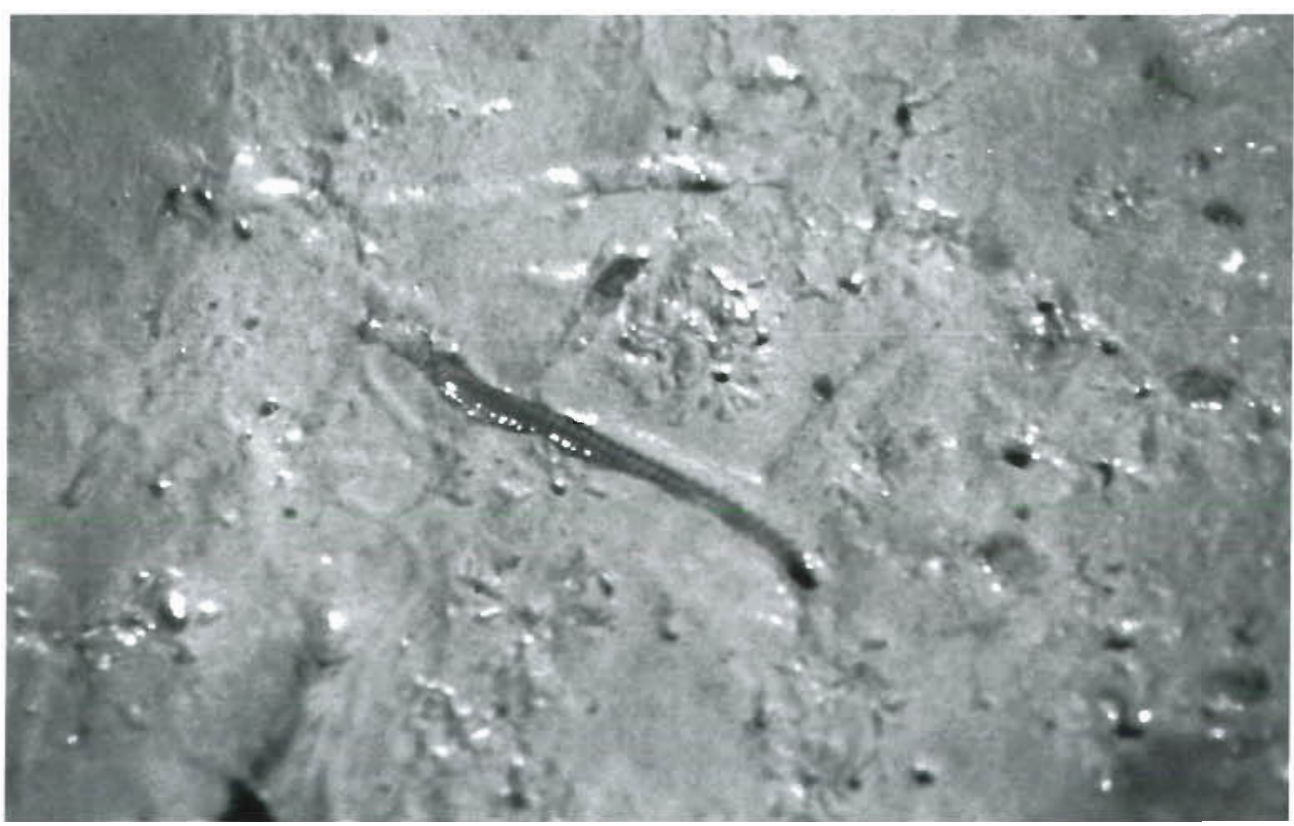

Fig. 1 A Nereis diversicolor which has emerged from its burrow to surface deposit feed. The furrows formed by the feeding by neighbouring worms are also visible 
200 Corophium volutator (equivalent to $13000 \mathrm{~m}^{-2}$ ) were added to each of 5 cores, 35 Nereis diversicolor (equivalent to $2300 \mathrm{~m}^{-2}$ ) were added to each of a further 5 cores, and 5 cores with no macrofauna were left as controls. Surface scrapings of a diatomaceous film from near the experimental field sites were mixed into a slurry with a little water and similar amounts spread evenly on the surface of each core to a depth of $0.5 \mathrm{~cm}$. A length of plastic tube $(5 \mathrm{~mm}$ diameter) was inserted through the sediment to facilitate drainage on emersion, and a mesh was placed over the top of each corer to retain the animals. After $8 \mathrm{~d}$ the diatoms in each core were sampled by taking 3 small sediment samples, $2 \mathrm{~cm}$ in diameter and $1 \mathrm{~cm}$ deep. These samples were placed in individual tubes containing $1 \%$ glutaraldehyde solution and kept at $9^{\circ} \mathrm{C}$ in the dark until used. Each core of sediment was sieved through a $0.354 \mathrm{~mm}$ sieve and the surviving macrofauna counted

Field experiments. The field experiments were conducted in Clementsgreen Creek, a branch of the River Crouch approximately $15 \mathrm{~km}$ from the open sea (Fig. 2). The only macrofaunal species in the sediment in some troughs between residual mud mounds in a small bay off the creek was Corophium volutator, while approximately $200 \mathrm{~m}$ further up the creek the sediment contained only Nereis diversicolor

Five Corophium volutator exclusion areas, each $25 \mathrm{~cm}$ $\times 25 \mathrm{~cm}$, were established, each with a similas control area approximately $50 \mathrm{~cm}$ away. The exclusion areas were subjected to weekly applications of a pyrethrumbased insecticide (Bug Gun, ICI) from 12 October to 9 November 1993 to remove any amphipods (see Gerdol \& Hughes 1993). Similarly, 5 Nereis diversicolor exclusion areas were established, each with a control area nearby. The deep burrowing worms are relatively unaffected by applications of insecticide and the worms could not be removed without sieving and disrupting the sediment. Instead in the exclusion areas surface deposit feeding by $N$. diversicolor was prevented by removing a slab of sediment 2 to $3 \mathrm{~cm}$ thick and inserting a mat of netting of $0.5 \mathrm{~mm}$ mesh size in the hole before replacing the surface sediment. The control areas underwent the same treatment but without insertion of the mat. This experiment lasted $6 \mathrm{wk}$, from 19 October to 30 November 1993.

$A$ : the end of the field experiments diatoms were collected in 5 core samples, $2 \mathrm{~cm}$ diameter and $1 \mathrm{~cm}$ deep, from each exclusion and control area, and treated in the same way as the laboratory diatom samples. To sample the macrofauna 3 cores were taken from each control and exclusion area using a corer of $3.8 \mathrm{~cm}$ diameter These cores were $10 \mathrm{~cm}$ deep in the Corophium volutator experiment, $15 \mathrm{~cm}$ deep in the Nereis diversicolor control areas, and down to the mats in the exclusion arecs to capture any worms recruited during the experiment. These cores were sieved (mesh size $0.354 \mathrm{~mm}$ ) and the macrofauna present were identified and counted.

Treatment of diatom samples. Each sample was sonicated (L \& R, Ultrasonicator) for 7 min, which separates the diatoms from the sediment, but does not destroy them (Paterson et al. 1990). A constant volume $(0.53 \mathrm{ml})$ of this suspension was added to a Lund chamber and the number of diatoms in half the chamber counted at a magnification of $\times 300$. Two subsamples from each diatom sample were used to calculate the density of diatoms in the field and laboratory experiments.

The specific compositions of the diatom assemblages were determined at the same time as their densities. From each Lund chamber sample 50 randomly selected diatoms were identified to genus, and to species if possible, and given a code letter. Later, to confirm the species identities several samples of sediment were cleaned by washing with distilled water and then centrifuged at $7000 \times g$ for $3 \mathrm{~min}$. This procedure was repeated 4 times, removing the supernatant and replacing it with distilled water each time. The cleaned sample with some distilled water was added to an equal volume of nitric acid and placed on a hot plate until half the volume had evaporated. The solution was washed with distilled water and centrifuged a further 5 times. A small drop of this sample was placed on a
Fig. 2. The study area showing location of the Corophium volutator experiments $(\mathrm{C})$ and the Nereis diversicolor experiments $(\mathrm{N})$
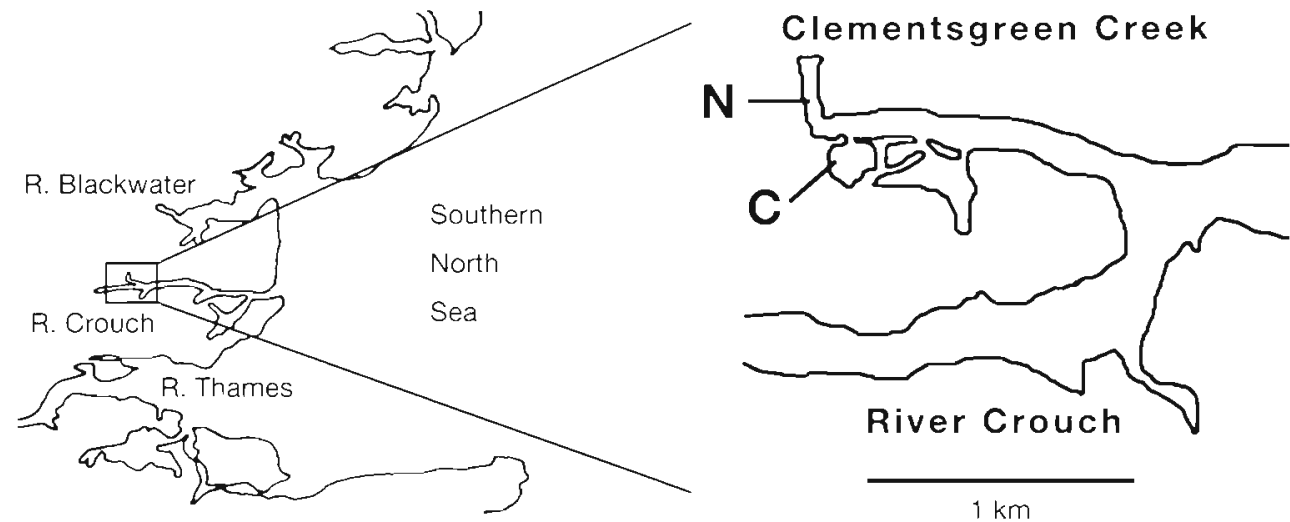
coverslip, dried and mounted in Naphrax. All the diatoms were identified to genus and, in most cases, to species. Cluster analyses of the diatom assemblages were performed using percentage similarity for sample comparisons and unweighted pair groups as the clustering method

Calculation of rates of predation. These calculations were based on 2 assumptions: firstly, that the diatom. densities in the control and exclusion areas at the start of the experiments were not different, and secondly that the higher diatom densities in the exclusion areas at the end of the experiments were due to reduced rates of predation, as any other extrinsic factor affected diatom abundance equally in the control and exclusion areas. On these assumptions, the mean daily rates of consumption of diatoms by individual worms and amphipods in the control areas in the field experiments were equal to the mean daily rates of increase in diatom densities in the exclusion areas.

The daily rates of increase in diatom densities were calculated in 2 ways. The first method presumed that there was a constant rate of increase of diatom densi- ties in the exclusion areas relative to the control areas, while the second method presumed a constant reproduction rate (which would lead to an exponential rate of increase in densities). The first method use the following formula:

$$
C=\frac{D_{e}-D_{c}}{\left(A_{c}-A_{e}\right) T}
$$

where $C$ is mean daily individual consumption number of diatoms); $D_{\mathrm{e}}$ is the mean density of diatoms in the exclusion areas, and $D_{c}$ the mean density in the control areas; $A_{c}$ is the mean number of animals in the control areas, and $A_{\mathrm{e}}$ the mean number of animals in the exclusion areas; $T$ is the duration of the experiment in days.

In the second method the rate of reproduction $(R)$ of the diatoms was calculated using the following formula:

$$
R^{r}=\frac{D_{\mathrm{e}}}{D_{\mathrm{c}}}
$$

This reproduction rate was used to calculate a daily rate of increase by multiplying the mean control density by $R$
Table 1 Species of diatoms found, together with their sizes, based on Hendey (1964), and Krammer \& Lange-Bertalot $(1986,1988)$, and a code letter referred to

\begin{tabular}{|c|c|c|c|}
\hline Code & Species & Length $(\mu \mathrm{m})$ & Width $(\mu \mathrm{m})$ \\
\hline A & Navicula arenaria Donkin & $30-80$ & $8-11$ \\
\hline $\mathrm{B}$ & Navicula crucicula (W. Smith) Donkin & $40-52$ & 16 \\
\hline $\mathrm{C}$ & Navicula halophila (Grunow) Cleve & 53 & 12 \\
\hline $\mathrm{D}$ & Navicula phyllepta Kützing & $30-50$ & 8 \\
\hline $\mathrm{E}$ & Navicula ramosissima (Agardh) Cleve & $34-43$ & 8 \\
\hline $\mathrm{F}$ & Parlibellus berkeleyi (Kutzing) E. J. Cox & $12-30$ & $5-7$ \\
\hline $\mathrm{G}$ & Amphora coffeaeformis (Agardh) Kutzing & $30-50$ & $<25$ \\
\hline $\mathrm{H}$ & Nitzschiasp. A & & \\
\hline I & Nitzschia sp. B & & \\
\hline $\mathrm{J}$ & Nitzschia apiculata (Gregory) Grunow & $20-58$ & $4.5-8.5$ \\
\hline $\mathrm{K}$ & Nitzschia bilobata W. Smith & $90-110$ & $15-18$ \\
\hline $\mathrm{L}$ & Nitzschia closterium \{Ehrenberg\} Kützing & $50-80$ & $<5$ \\
\hline M & Surirella sp. A & & \\
\hline $\mathrm{N}$ & Surirella gemma (Ehrenberg) Kutzing & $72-140$ & $53-56$ \\
\hline 0 & Surirella ovalis Brébisson & $45-80$ & 12 \\
\hline $\mathrm{P}$ & Diploneis elliptica (Kützing) Cleve & $20-130$ & $10-60$ \\
\hline$Q$ & Diploneis didyma (Ehrenberg) Cleve & $30-90$ & $15-36$ \\
\hline $\mathrm{R}$ & $\begin{array}{l}\text { Pleurosigma angulatum } \\
\text { (Quekett) W. Smith var. angulatum }\end{array}$ & $150-360$ & $30-60$ \\
\hline $\mathrm{s}$ & $\begin{array}{l}\text { Pleurosigma angulatum var undulatum } \\
\text { Grunow }\end{array}$ & \multicolumn{2}{|c|}{ Narrower than angulatum } \\
\hline $\mathrm{T}$ & Pleurosigma intermedum W. Smith & $126-194$ & $17-18$ \\
\hline $\mathrm{U}$ & Gyrosigma balticum (Ehrenberg) Cleve & $236-500$ & $28-32$ \\
\hline V & Gyrosigma hippocampus (Ehrenberg) Hassell & Il $142-180$ & $22-26$ \\
\hline W & Gyrosigma littorale (W. Smith) (leve & $100-160$ & $22-35$ \\
\hline$x$ & $\begin{array}{l}\text { Gyrosigma obscurum (W. Smith) } \\
\text { Griggith \& Henfrey }\end{array}$ & $80-200$ & $10-15$ \\
\hline Y & Gyrosigma wansbeckii (Donkin) Cleve & $100-190$ & $13-15$ \\
\hline
\end{tabular}
in the text, figures and other tables

\section{RESULTS}

The diatom species recorded are listed in Table 1 with their approximate sizes and code letter which is used to identify them in subsequent figures

\section{Laboratory experiments}

The mean densities of animals alive during the experiments, calculated as the mean of the initial densities and the final densities, were 9804 ( \pm 145 SE) $\mathrm{m}^{-2}$ for Corophium volutator and 2052 ( $\pm 51 \mathrm{SE}$ ) $\mathrm{m}^{-2}$ for Nereis diversicolor. At the end of the experiments the mean density of diatoms in the control cores $\left(35.1 \times 10^{8} \mathrm{~m}^{-2}\right)$ was significantly higher than the densities in cores containing $C$. volutator $\left(15.4 \times 10^{8} \mathrm{~m}^{-2}\right)$ $(p<0.001, t$-test) and those containing $N$. diversicolor $\left(14.2 \times 10^{8} \mathrm{~m}^{-2}\right)(\mathrm{p}<$ 0.001 , $t$-test). The densities of most diatom taxa were lower in the presence of $C$. volutator and $N$. diversicolor (Figs. $3 \& 4$ ). The exceptions were Parlibellus berkeleyi (F), and Surirella sp. A (M), whose densities did not differ significantly in either experiment; Amphora coffeaeformis 


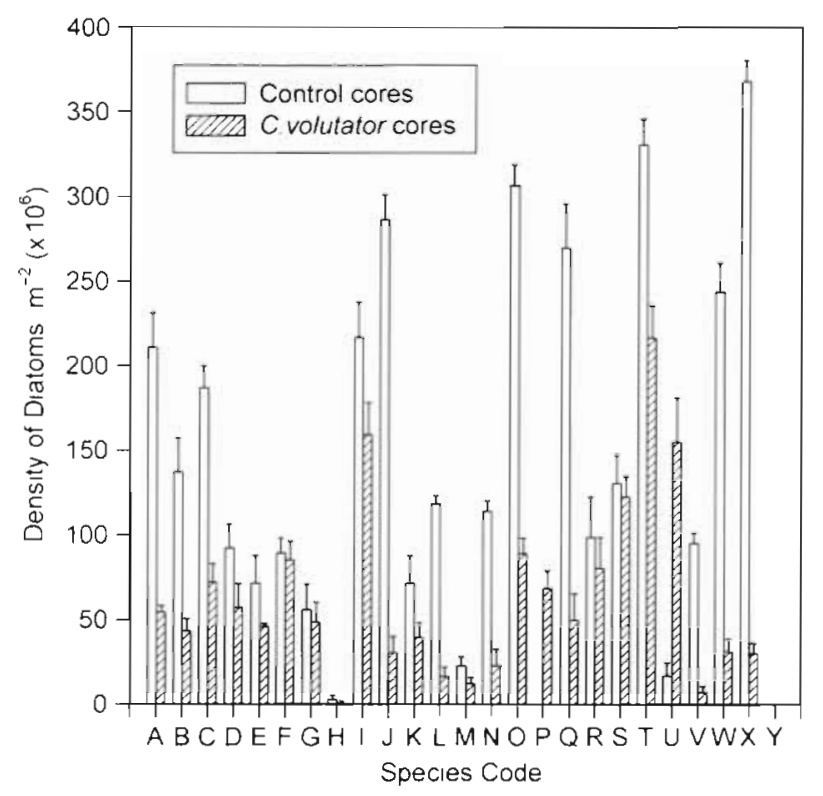

Fig. 3. Laboratory experiments. Mean density of the diatom taxa in control cores and in cores with Corophium volutator. Species codes are listed in Table 1

(G), Nitzschia sp. A (H) and the 2 Pleurosigma angulatum varieties ( $R$ and $S$ ), which showed no difference in the C. volutator experiment; and Navicula ramosissima (E) and Nitzschia bilobata (K), which showed no difference in the $N$. diversicolor experiment. Diploneis elliptica (P) and Gyrosigma balticum (U) had significantly higher densities in the presence of $C$. volutator and $N$. diversicolor.

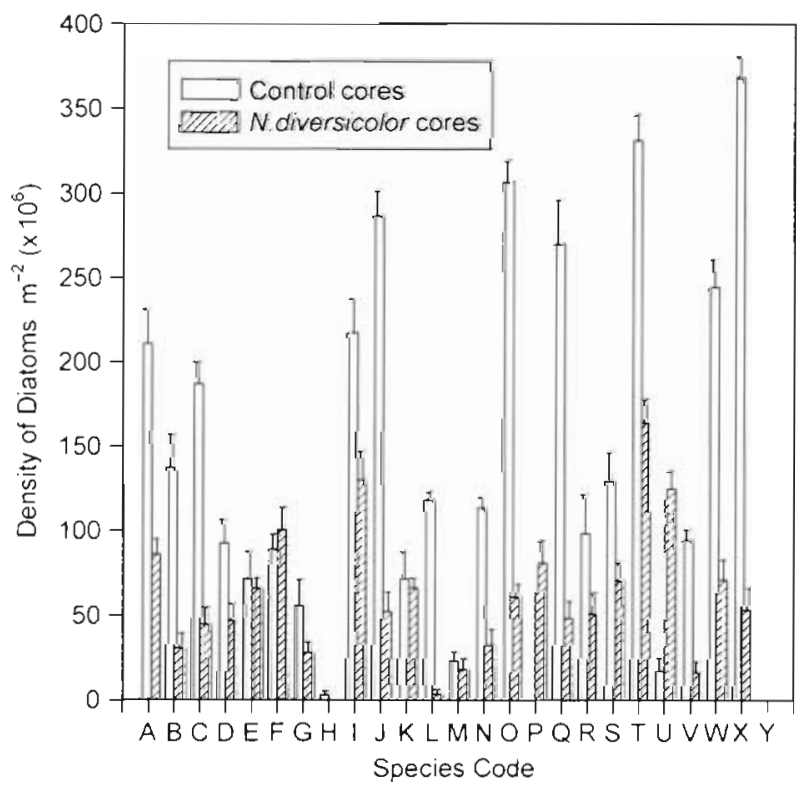

Fig. 4. Laboratory experiments. Mean density of the diatom taxa in control cores and in cores with Nereis diversicolor. Species codes are listed in Table 1

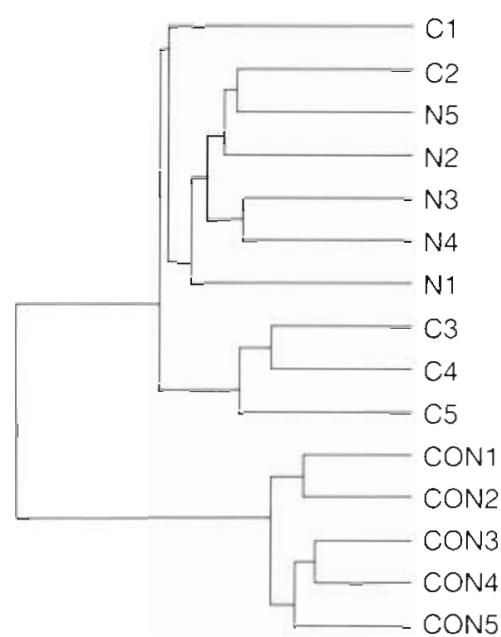

Fig. 5. Laboratory experiments. Dendrogram showing the clustering of the diatom assemblages in the cores with Corophium volutator (C), Nereis diversicolor (N), and the control cores (CON)

The specific compositions of the diatom samples from each core are available from R. G. Hughes. Cluster analysis revealed 2 distinct groups, one group containing only the control cores and the other containing the cores with animals (Fig. 5). These groups were separated largely because in the control cores there was a higher relative abundance of Nitzschia apiculata (J), N. closterium (L), Surirella ovalis (O), Diplonejs didyma (Q), Gyrosigma hippocampus (V), G. littorale (W), and G. obscurum (X), a lower relative abundance of Nitzschia sp. B (I), Pleurosigma angulatum var. undulata (S), and G. balticum (U), and no Diploneis elliptica (P).

\section{Field experiments}

One of the Corophium volutator exclusion areas and its control was damaged and the results from only the remaining 4 pairs of areas are presented. The mean densities of $C$. volutator, Nereis diversicolor and the diatoms in the exclusion and control areas of both experiments are shown in Fig. 6. The insecticide treatment removed all the amphipods from the exclusion areas, and the sub-surface mats reduced the density of surface deposit feeding worms by approximately $80 \%$. The mean densities of diatoms increased by a factor of 2.9 in the $C$ volutator exclusion areas and by a factor of 4.3 in the $N$. diversicolor exclusion areas. The calculated daily rate of predation by individual $C$. volutator was 3767 diatoms, assuming a constant rate of diatom increase, and 2150 diatoms, assuming a constant rate of reproduction. The respective figures for $N$. diversicolor were 12184 and 5476 diatoms $\mathrm{d}^{-1}$. 

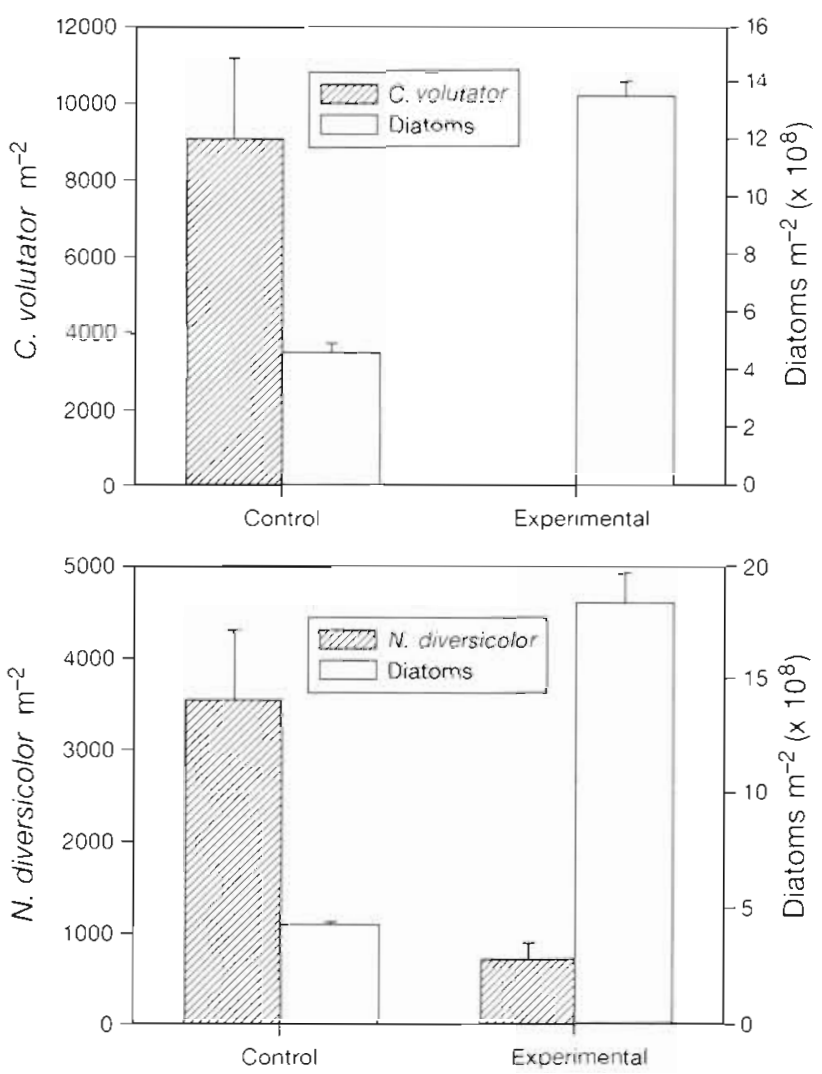

Fig. 6. Freld experiments. Mean densities of the macrofauna and diatoms in control areas and experimental exclusion areas in both field experiments

In both experiments the mean densities of all diatom taxa in the control areas were significantly lower than in the exclusion areas, with only 5 exceptions (Figs. 7 \& 8). These were Nitzschia sp. B (I), N. bilobata (K), and Gyrosigma wansbeckii $(\mathrm{X})$ in the Corophium volutator experiment, and Surirella sp. A (M) and Pleurosigma intermedium ( $\mathrm{T}$ ) in the $N$. diversicolor experiment.

The specific compositions of the diatom samples from the Corophium volutator experiment and the Nereis diversicolor experiment are available from R. G. Hughes. The samples had a high equitability (evenness) which means that the differences that led to the formation of the clusters in the dendrogram, shown in Fig. 9, cannot be attributed easily to a small number of species. Rather the clustering is due to cumulative small differences in abundance of many taxa. The samples form 2 major clusters, one for the $C$. volutator experiment and the other for the $N$. diversicolor experiment. This separation is due mainly to the higher relative abundance of Navicula crucicula (B), Surirella gemma (N), Diploneis didyma (Q), and Gyrosigma hippocampus (V), in the $C$. volutator area compared to the $N$. diversicolor area, where there was a higher relative abundance of both Pleurosigma angulatum varieties (R and S) and G. obscurum (X).

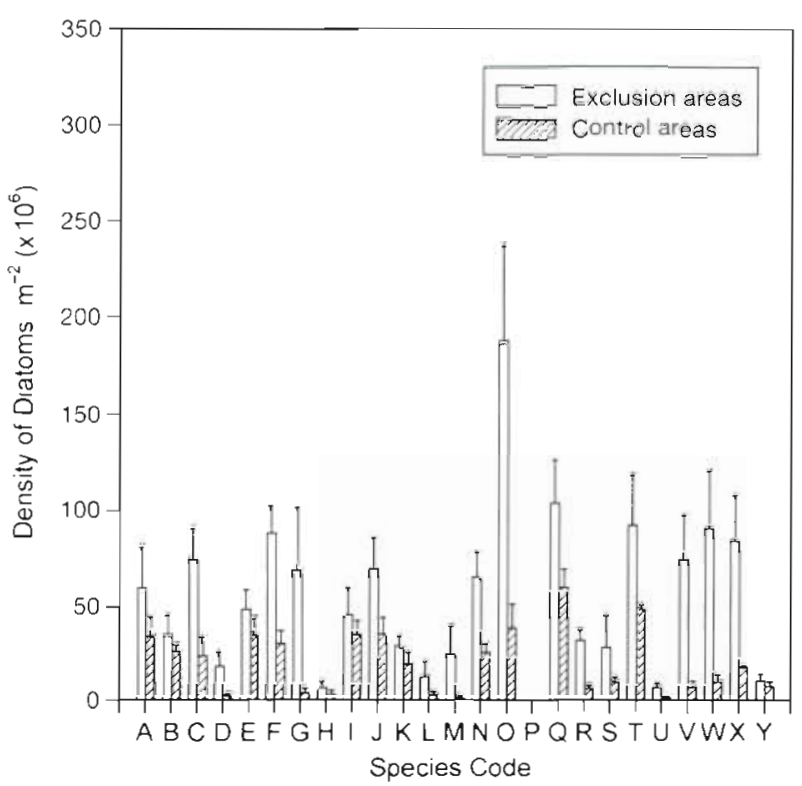

Fig. 7. Fleld experiments. Mean density of the diatom taxa in control areas and in Corophium volutator exclusion areas. Species codes are listed in Table 1

Within the cluster from the Nereis diversicolor experiment the samples separate into a group comprising the control areas and another consisting of the exclusion areas, with exclusion area N4 as an outlier. The 2 groups are formed largely because there were relatively low abundances of Pleurosigma intermedium $(\mathrm{T})$, and relatively high abundances of Gyrosigma obscurum (X), in the exclusion areas.

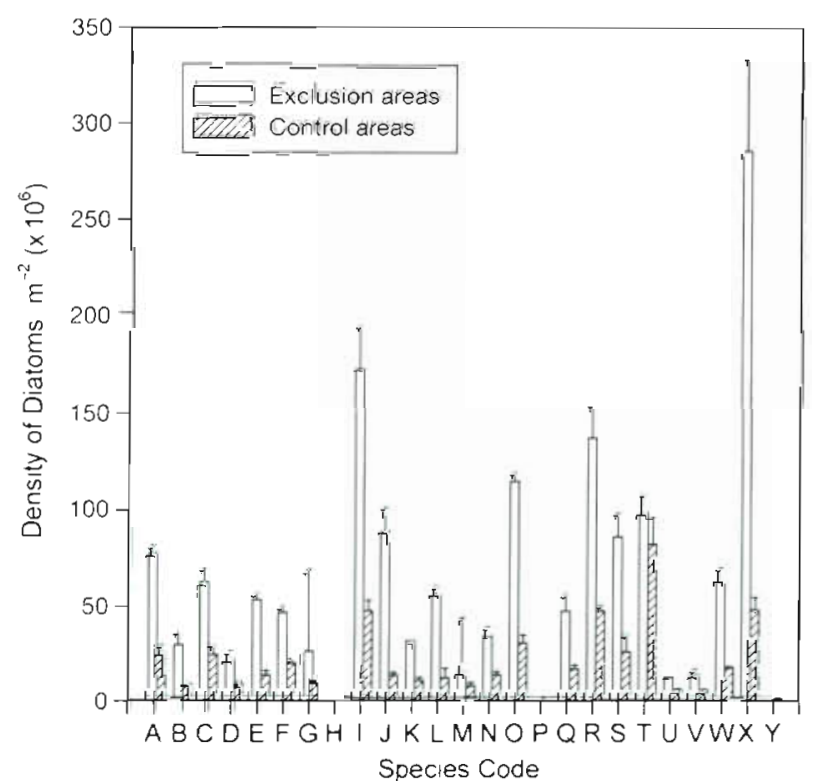

Fig. 8. Field experiments. Mean density of the diatom taxa in control areas and in Nereis diversicolor exclusion areas. Species codes are listed in Table 1 


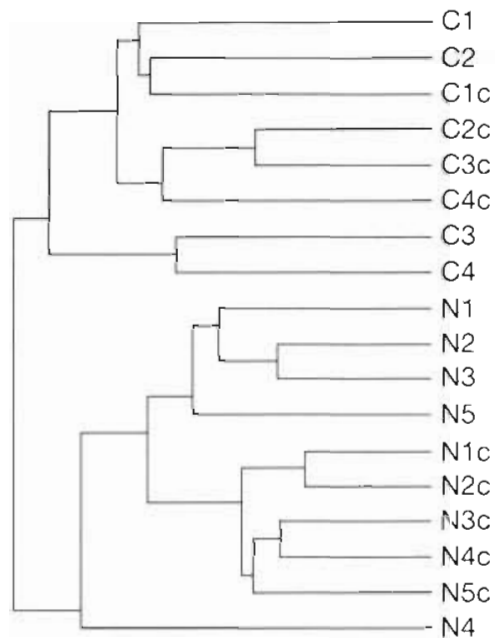

Fig. 9. Field experiments. Dendrogram showing the clustering of the datom assemblages in the Corophium volutator exclusion areas $(\mathrm{C} n)$, the $\mathrm{C}$. volutator control areas $(\mathrm{CnC})$, the Nereis diversicolor exclusion areas $(\mathrm{N} n)$, and the $N$. diversicolor control areas $(\mathrm{N} n \mathrm{C})$

The samples from the Corophium volutator experiment form 3 groups. One group, consisting of control areas 2, 3 and 4, was characterised by relatively high abundances of Navicula ramosissima (E), Nitzschia sp. $\mathrm{B}$ (I) and Diploneis didyma (Q), and a relatively low abundance of Gyrosigma hippocampus (V). Control area 1 is separated from the other control areas and clusters with exclusion areas 1 and 2, largely because of a relatively high abundance of Navicula arenaria (A) and Nitzschia closterium (L), and a low relative abundance of Navicula ramosissima (E). Exclusion areas 3 and 4 cluster because of their relatively low abundance of Navicula arenaria (A), Nitzschia apiculata (J), Diploneis didyma (Q), but a relatively high abundance of Navicula halophila (C), Amphora coffeaeformis (G) and $G$. hippocampus (V)

\section{DISCUSSION}

The results from the laboratory and field experiments demonstrate that both Corophium volutator and Nereis diversicolor markedly reduce the abundance of epipelic diatoms. The results for C. volutator confirm those of Gerdol \& Hughes (1994b), who demonstrated that the amphipods caused significant decreases in the abundance of epipelic diatoms, due to their feeding rather than bioturbation. In this study the effects of $N$. diversicolor, in the laboratory at least, were also a result of their feeding, since as the animals had already burrowed no bioturbation occurred other than that associated with feeding. The presence of feeding tracks on the mudflats also points to sur- face deposit feeding as the major cause of decreased diatom abundance in the estuary.

The daily rates of predation calculated from the field experiments indicate that the mean daily consumption rate of an individual Nereis diversicolor is 4 to 5 times that of an individual Corophium volutator, an expected result as the worms are larger. The total number of diatoms consumed by these populations during the field experiments were estimated to be 18.0 to $31.5 \times 10^{6} \mathrm{~m}^{-2}$ $\mathrm{d}^{-1}$ for C. volutator (at $8375 \mathrm{~m}^{-2}$ ), and 19.3 to $42.9 \times 10^{6}$ $\mathrm{m}^{-2} \mathrm{~d}^{-1}$ for $N$. diversicolor (at $3562 \mathrm{~m}^{-2}$ ). These are the first such estimates of this kind to be calculated.

Despite these apparently high rates of consumption the calculated constant daily reproduction rates of the diatoms in the Corophium volutator and Nereis diversicolor exclusion areas were very similar, but low, at 1.038 and 1.035 respectively. These figures indicate a doubling time of approximately $20 \mathrm{~d}$, much lower than that achieved in the laboratory where doubling times of fractions of a day to a few days have been obtained in experiments with unialgal cultures (e.g. Cox 1993. 1994). Small diatoms tend to divide more rapidly than large ones. For example, Amphora coffeaeformis divided several times a day $(k>3$ ) (in $50 \%$ seawater, $20^{\circ} \mathrm{C}$ and $14 \mathrm{~h}$ light/10 h dark), while under similar conditions Nitzschia scalpelliformis only divided once a day, and the much larger Pinnularia viridis took 3 to 5 d per division. G. Reid (Natural History Museum; unpubl.) observed that doubling times in Gyrosigma spp. varied between 1 and $3 \mathrm{~d}$ according to temperature, light and salinity regime.

The relatively low rates of reproduction calculated in the field experiments may indicate that there were other environmental limitations on diatom densities. These include predation by meiofaunal organisms, particularly nematodes which are abundant in these estuaries. Predation by meiofauna on the smaller diatoms may also explain why these species in particular did not have a more marked increase in abundance.

In the laboratory experiments the estimated mean daily consumption rates were approximately 10 times higher than those from the field experiments, at 25000 diatoms for Corophium volutator and 125000 for Nereis diversicolor (assuming a constant rate of diatom depletion over the $8 \mathrm{~d}$ ). The laboratory results were obtained under conditions where the animals were at relatively low densities, the diatoms at relatively high densities, and where no food in suspension was available. However, they indicate that potential food consumption by both species is much higher than that achieved in situ where food may be limiting.

Intraspecific competition may reduce consumption rates by Corophium volutator at high densities (see Jensen \& Kristensen 1990) and food supply may limit $C$. volutator growth rate and abundance at certain 
times of the year Stuart et al. (1985) concluded that diatoms offer a superior food source during the summer but are less important in spring and autumn. Gerdol \& Hughes (1993) reported densities of $C$. volutator greater than $100000 \mathrm{~m}^{-2}$, and densities of Nereis diversicolor of over $50000 \mathrm{~m}^{-2}$ were recorded by Möller (1985), but at these high densities the animals are probably smaller than those used in this study, and presumably had lower individual food requirements and consumption rates.

Epipelic diatoms are important in estuarine ecosystems; they may contribute up to one-third of the fixed carbon of an estuary (Underwood \& Paterson 1993a). and increase the resistance of the sediment to erosion by the production of mucopolysaccharides during their short vertical migrations (Holland et al. 1974, Paterson. et al. 1990, Round et al. 1990, Underwood \& Paterson $1993 a$, b). Predation on epipelic diatoms by Corophium volutator and Nereis diversicolor may, therefore, have several important consequences for the functioning of the estuarine ecosystem by reducing primary production, facilitating energy transfer from primary producers to secondary consumers, including birds and fish, and increasing sediment erosion. Gerdol \& Hughes (1994b) demonstrated that $C$. volutator made the sediment more susceptible to erosion by eating diatoms. More studies are required to quantify more accurately the effects of predation, on primary and secondary production, and to investigate seasonal differences.

Corophium volutator and Nereis diversicolor may alter the specific composition of epipelic diatom assemblages. When offered samples from the same diatom assemblage in the laboratory, the 2 species had similar effects on the relative abundance of the diatom taxa. This observation, together with the indication that food may be limiting (see above), leads to the conclusion that under some natural conditions where both species coexist interspecific competition may be an important factor in determining their abundances.

Most diatom species had lower densities in the cores containing animals than in the control cores. Predation had no significant effect on the density of some species, while Diploneis elliptica (P) and Gyrosigma balticum (U) densities increased in the presence of animals in both experiments. The reasons why different species are affected differently need further investigation but may include one or more of the following: both Corophium volutator and Nereis diversicolor consume preferentially certain diatom species; consumption is unselective but some species become relatively more abundant because they have higher reproductive rates; some diatom species are better adapted to the different interspecific competitive environment or to the different chemical environment created by the animals activities.
Increases in the density of Diploneis elliptica (P) and Gyrosigma balticum (U) in the presence of the animals in the laboratory experiments may be related to their large robust cells; $D$. elliptica is highly silicified and $G$. balticum has the largest cells in this assemblage. Gerdol \& Hughes (1994a) concluded that diatoms were crushed by the mandibles of Corophium volutator, since no diatom frustules were found in the guts of amphipods that had consumed large numbers. This indicates that diatoms may be manipulated individually introducing an opportunity for selection, perhaps by size, shape or hardness. Selectivity would not be expected of Nereis diversicolor as they ingest relatively large volumes of surface sediment. The diatom species whose relative abundance decreased show a wide range of sizes and shapes, indicating that selective feeding by the animals may not be important.

In the field experiments a similar comparison of the effects of Corophium volutator and Nereis diversicolor on diatom species abundances could not be made, for the diatom assemblages differed between the 2 sites. This probably reflected the contrasting physical environments of the 2 sites; the $C$. volutator site was more sheltered than the creek where the $N$. diversicolor experiments were conducted. Colijn \& Dijkema (1981) reported that the species composition of epipelic diatoms may vary along an exposure gradient.

That Corophium volutator and Nereis diversicolor differentially reduce the abundance of diatom species may have consequences for sediment stability, for Holland et al. (1974) found interspecific differences in the ability of epipelic diatoms to stabilise sediment with their secretions. Madsen et al. (1993) recorded an increase in sediment stability corresponded with an increase in the volume of Navicula, Amphora, and Nitzschia species, as well as the larger sigmoid genera Gyrosigma and Pleurosigma. It is perhaps significant that species of these 5 genera increased both in relative abundance and absolute density in the field exclusion areas. Predation may, therefore, reduce sediment stability, not only by reducing overall diatom densities, but also by reducing particularly the densities of those diatoms best able to stabilise sediments with their secretions.

\section{LITERATURE CITED}

Bornsdorff E, Medulla J, Ronn C, Österman C (1986) Multidimensional interactions in shallow soft-bottom ecosystems; testing the competitive exclusion principle. Ophelia, Suppl 4:37-44

Colijn F, Dijkema KS (1981) Species composition of benthic diatoms and distr.bution of chlorophyll $a$ on an intertıdal flat in the Dutch Wadden Sea. Mar Ecol Prog Ser 4:9-21

Cox EJ (1993) Freshwater diatom ecology: developing an experimental approach as an aid to interpreting field data. 
Hydrobiologia 269/270:447-452

Cox EJ (1994) Ecological tolerances and optima-real or imaginary? Verh Int Verein Limnol 25:2238-2241

Davey JT (1994) The architecture of the burrow of Neres diversicolor and its quantification in relation to sediment water exchange. J Exp Mar Biol Ecol 179:115-129

Esselink P, Zwarts L (1989) Seasonal trend in burrow depth and tidal variation in feeding activity of Nereis diversicolor. Mar Ecol Prog Ser 56:243-254

Fauchald K, Jumars PA (1979) The diet of worms: a study of polychaete feeding guilds. Oceanogr Mar Biol Annu Rev $17: 193-284$

Flach EC (1992) The influence of four macrozoobenthic species on the abundance of the amphipod Corophum volutator on tidal flats of the Wadden Sea. Neth J Sea Res 29:379-394

Gerdol V. Hughes RG (1993) Effect of the amphipod Corophiun volutator on the colonisation of mud by the halophyte: Salicornia europaea. Mar Ecol Prog Ser 97 $61-69$

Gerdol V. Hughes RG (1994a) Feeding behaviour and diet of Corophium volutator in an estuary in southeastern England. Mar Ecol Prog Ser 114:103-108

Gerdol V. Hughes RG (1994b) Effect of Corophium volutator on the abundance of benthic diatoms, bacteria and sediment stability in two estuaries of southeastern England. Mar Ecol Prog Ser 114:109-115

Harley MB (1950) Occurrence of a filter-feeding mechanism in the polychaete Nereis diversicolor. Nature 165:735

Hendey NI (1964) An introductory account of the smaller algae of British coastal waters. Part V: Bacillariophyceae (Diatoms). Fisheries lnvestigation Series IV. HMSO. London

Holland AF, Zingmark RG, Dean JM (1974) Quantıtative ev1dence concerning the stabilization of sediments by manne benthic diatoms. Mar Biol 27:191-196

Hughes RG, Gerdol V (in press) Factors affecting the distribution of Corophium volutator in two estuaries in south eastern England. Estuar Coast Shelf Sci

Jensen KT (1988) Recruitment and survival of Nereis diversicolor O.F. Muller and Corophium volutator (Pallas) in an artificial saltwater lagoon in the Danish Wadden Sea. Kiel Meeresforsch 6:366-373

Jensen KT, Andre C (1993) Field and laboratory experiments on interactions among an infaunal polychaete, Nereis diversicolor, and two amphipods, Corophium volutator \& $C$. arenarium: effects on survival, recruitment and migration. J Exp Mar Biol Fcol 168:259-278

Jensen KT, Kristensen LD (1990) A field expernment on competition between Corophium volutator (Pallas) and Corophium arenarium Crawford (Crustacea: Amphipoda): effects on survival, reproduction and recruitment. J Exp Mar Biol Ecol 13;:1-24

Krammer K, Lange-Bertalot H (1986) Bacillariophyceae. Teil 1.
Naviculaceae. Süßwasserflora von Mitteleuropa, Bd. 2, begr, von A. Pascher. Gustav Fischer Verlag, Stuttgart

Krammer K, Lange-Bertalot H (1988) Bacillariophyceae. Teil 2. Bacllariaceae, Epithemiaceae, Surirellaceae. Süßwasserflora von Mitteleuropa, Bd. 2, begr, von A. Pascher. Gustav Fischer Verlag, Stuttgart

Madsen KN, Nelson P. Sundback K (1993) The influence of benthic microalgae on the stability of a subtidal sediment. J Exp Mar Biol Ecol 170: 159-177

Mnadows PS, Reid A (1966) The behaviour of Corophium volutator (Crustacea: Amphipoda). J Zool (Lond) 150: $387-399$

Meadow's PS, Tait J (1989) Modification of sediment permeabilhty and shear strength by two burrowing invertebrates. Mar Biol 101:75-82

Möller P (1985) Production and abundance of juvenile Nereis diversicolor and oogenic cycles of adults in shallow waters of western Sweden. J Mar Biol Ass UK 65:603-616

Moller P (1986) Physical factors and biological interactions regulating infauna in shallow boreal areas. Mar Ecol Prog Ser 30:33-47

Olafsson EB, Persson L (1986) The interaction between Nereis diversicolor O.F. Muller and Corophium volutator (Pallas) as a structuring force in a shallow brackish sediment. J Fxp Mar Biol Ecol 103:103-117

Pashley HE (1986) The foraging behaviour of Nereis diverstcolor. PhD thesis, University of Cambridge

Paterson DM, Crawford RM, Little C (1990) Subaerial exposure and changes in the stability of intertidal sediments. Estuar Coast Shelf Sci 30:541-556

Reise K (1979) Moderate predation on meiofauna by the macrobenthos of the Wadden Sea. Helgol Meeresunters $32: 453-465$

Rusgard HU (1991) Suspension feeding in the polychaete Neress diversicolor. Mar Ecol Prog Ser 70:29-37

Ronn C, Bonsdorff E, Nelson WG (1988) Predation as a mechanism of interference within infauna in shallow brackish water soft bottom; experiments with an infaunal predator, Neress diversicolor O. F. Muller. J Exp Mar Biol Ecol 116. $143-157$

Round FE, Crawford RM, Mann DG (1990) The diatoms. Biology \& morphology of the genera. Cambridge University Press, Cambridge

Stuart V, Head EJH, Mann KH (1985) Seasonal changes in the digestive enzyme levels of the amphipod Corophium volutator (Pallas) in relation to diet. $J$ Exp Mar Biol Ecol 88: 243-256

Underwood GJC, Paterson DM (1993a) Seasonal changes in dlatom biomass, sediment stability and biogenuc stabilization in the Severn Estuary. J Mar Biol Ass UK 73: $871-887$

Underwood GJC, Paterson DM (1993b) Recovery of intertidal benthic datoms after biocide treatment and associated sediment dynamics. J Mar Biol Ass UK 73:25-45

Manuscript first received: February 20, 1996

Revised version accepted: November 5,1996

This article was submitted to the editor 